\title{
High-mobility group box 1 is overexpressed in cervical carcinoma and promotes cell invasion and migration in vitro
}

\author{
XIAOAO PANG, YAO ZHANG and SHULAN ZHANG \\ Department of Gynecology and Obstetrics, Shengjing Hospital \\ of China Medical University, Heping, Shenyang, Liaoning 110004, P.R. China
}

Received June 3, 2016; Accepted July 9, 2016

DOI: $10.3892 /$ or.2016.5317

\begin{abstract}
The present study aimed to investigate the expression of high-mobility group box 1 protein (HMGB1) in cervical carcinoma and explore whether or not HMGB1 promotes cervical carcinoma cell invasion and migration in vitro and the related mechanism. HMGB1, nuclear factor- $\kappa \mathrm{B}(\mathrm{NF}-\kappa \mathrm{B})$, $\mathrm{E}$-cadherin and $\mathrm{N}$-cadherin protein expression was analyzed in tissues from 48 cervical carcinomas, 51 cervical intraepithelial neoplasia (CIN) and tissues from 24 healthy controls using immunohistochemistry. HeLa cells were treated with different concentrations of $\operatorname{HMGB1}(0,10,100$, and 1,000 ng/ml) at different time-points $(0,24,48$ and $72 \mathrm{~h})$, and changes in cell morphology and biological behaviors were observed. Changes in the expression levels of E-cadherin, $\mathrm{N}$-cadherin, $\mathrm{NF}-\kappa \mathrm{B}$ and the inhibitor $\kappa \mathrm{B}(\mathrm{I} \kappa \mathrm{B})$ in the treated cells were detected by western blot analysis and real-time PCR. HMGB1 expression exhibited a gradually increasing trend in the normal cervical tissues, CIN and cervical cancer, and there was statistical significance between the three groups $(\mathrm{P}<0.05)$. HMGB1 expression level was associated with FIGO stage, lymph node metastasis and differentiation $(\mathrm{P}<0.05)$. HMGB1 expression was positively related to $\mathrm{N}$-cadherin and $\mathrm{NF}-\kappa \mathrm{B}$; and $\mathrm{HMGB1}$ had a negative relationship with E-cadherin. HMGB1 stimulation caused HeLa cells to lose cell polarity and transition from epithelial cells into spindle-shaped cells with sparse cell-cell junctions. The expression levels of E-cadherin and $\mathrm{I} \kappa \mathrm{B}$ in the cytoplasm were reduced, while $\mathrm{N}$-cadherin expression was increased. The level of $N F-\kappa B$ expression in the nucleus was also increased. Treatment with $N F-\kappa B$ inhibitor (BAY11-7082) and receptor for advanced glycation end products (RAGE) antagonist (anti-RAGE) significantly suppressed HMGB1-mediated epithelial-to-mesenchymal transition in the
\end{abstract}

Correspondence to: Professor Shulan Zhang, Department of Gynecology and Obstetrics, Shengjing Hospital of China Medical University, 36 Sanhao Street, Heping, Shenyang, Liaoning 110004, P.R. China

E-mail: zhangs10909@hotmail.com

Key words: high-mobility group box 1 protein, cervical carcinoma, $\mathrm{NF}-\kappa \mathrm{B}, \mathrm{I} \kappa \mathrm{B}$, epithelial-to-mesenchymal transition
HeLa cervical cancer cells. The results suggest that HMGB1 is associated with outcomes of cervical cancer and promotes subsequent invasion and metastasis of cervical cancer cells by activating the $N F-\kappa B$ signaling pathway. This potential mechanism could be an important determinant of cervical cancer metastasis.

\section{Introduction}

Cervical cancer is a common gynecological tumor with a high incidence rate especially among younger population groups. Early detection and treatment are critical for cervical cancer prognosis. Effective treatment is challenging when cervical cancer is detected after metastasis has occurred, which diminishes the efficacy of surgical treatment. Hence, it is of great importance to identify the features of advanced cervical carcinoma and establish new therapeutic strategy for clinical treatments. However, the mechanism of cervical cancer metastasis has not been fully clarified. The epithelial-to-mesenchymal transition (EMT) of cervical cancer cells is closely related to the occurrence and development of epithelial malignancies, thus this is a research hotspot. The process of EMT occurs in multiple steps, with corresponding changes in cell polarity and mobility, which allows tumor cells to infiltrate surrounding tissue and metastasize to distant sites $(1,2)$. Important indicators of EMT include a reduction in E-cadherin expression levels and an increase in $\mathrm{N}$-cadherin expression levels $(1,2)$. Numerous in vitro and in vivo studies have suggested that EMT has a key role in the occurrence, development, and metastasis of many malignancies, such as colonic, breast, lung, cervical, pancreatic, and renal cancer. There are also reports that high-mobility group box 1 protein (HMGB1) induces tumor development, and HMGB1 is associated with invasion and metastasis of several types of tumors (3). HMGB1 activates mitogen-activated protein kinase (MAPK) and nuclear factor- $\kappa \mathrm{B}(\mathrm{NF}-\kappa \mathrm{B})$ pathways. During cell stimulation, cytoplasmic inhibitor $\kappa \mathrm{B}(\mathrm{I} \kappa \mathrm{B})$ is phosphorylated and degraded causing $\mathrm{NF}-\kappa \mathrm{B}$ release which is correlated with EMT in many tumor types (4,5). However, whether HMGB1 promotes invasion and metastasis of cervical carcinoma and the related mechanisms remain to be investigated. Combining international research findings and preliminary study results, we hypothesized that HMGB1 facilitates the invasion and migration of cervical cancer by activating the $\mathrm{NF}-\kappa \mathrm{B}$ signaling 
pathway. This study was designed as an experiment to explore the expression of HMGB1 in cervical tissues and the effects of HMGB1 on invasion and migration in cervical cancer cells and the relevant mechanism, which will provide a new strategy for the prevention and treatment of cervical cancer and a potential oncogenic biomarker and therapeutic target for late-stage and metastatic cervical cancer patients.

\section{Materials and methods}

Patients and samples. All 123 cervical samples were collected from patients who had undergone surgery at Shengjing Hospital (Shenyang, Liaoning, China) between 2011 and 2013. The specimens included 48 locally advanced invasive cervical cancers (ICC), 51 cervical intraepithelial neoplasia (CIN), and 24 normal squamous epithelial specimens (NSCES). The median age of all patients was 44 years (range, 19-74 years). Normal squamous epithelial specimens were collected from uteri of patients who had undergone hysterectomy without malignancy. This study was approved by the Ethics Committee of China Medical University, and informed written consent was obtained from all subjects prior to the study.

A histopathological diagnosis of cancer was based on World Health Organization classifications, and the clinical staging was defined according to the International Federation of Gynecology and Obstetrics (FIGO) system. Complete clinical and pathological data were available for all patients, and none had received pre-operative radiotherapy, chemotherapy, or biological therapy.

Immunohistochemistry. The tissues were embedded in paraffin and fixed in $4 \%$ formaldehyde, and serial sections were used. We used mouse anti-HMGB1 at 1:40 (R\&D Systems, Inc., Minneapolis, MN, USA); rabbit anti-NF- $\kappa \mathrm{B}$ at 1:100, rabbit anti-N-cadherin at 1:100 and rabbit anti-E-cadherin at 1:200 (all from ProteinTech Group, Inc., Chicago, IL, USA). Phosphate-buffered saline (PBS) was substituted for the primary antibody in the negative control. Serial sections were used for all single staining to show that HMGB1, NF- $\kappa \mathrm{B}$, $\mathrm{E}$-cadherin and $\mathrm{N}$-cadherin were related. After overnight incubation at $4^{\circ} \mathrm{C}, 3$ washes in PBS were performed. The procedure was based on the SP kit system (Zhongshan Golden Bridge Biotechnology Co., Ltd., Beijing, China). Two researchers who were blinded to the patient materials examined the immunostained slides with microscopy in a bright-field. To assess immunostaining data for HMGB1, NF- $\kappa \mathrm{B}$, E-cadherin and $\mathrm{N}$-cadherin, an immunostaining scoring system corresponding to total staining intensity was as follows: strong staining, 3; moderate staining, 2; weak staining, 1; no staining, 0. Scores for the relative numbers of positive cells were as follows: $>75 \%$ of cells were positive, $4 ; 51-75 \%$ of cells were positive, 3 ; $25-50 \%$ of cells were positive, $2 ;<25 \%$ of cells were stained positive, 1 ; no positive cells, 0 . The scores of percentage and intensity reflect the sums of scores, with total scores of 0 indicated as (-); total scores of 1-2 as (+); total scores of 3-5 as (++); total scores of 6-7 as $(+++)$.

Cell culture. HeLa cells (Institute of Biochemistry and Cell Biology, Shanghai, China) were maintained in Dulbecco's modified Eagle's medium (DMEM)/high glucose (HyClone,
Logan, UT, USA). Media were supplemented with $10 \%$ fetal bovine serum (FBS) (ExCell Bio, Shanghai, China), and cells were cultured at $37^{\circ} \mathrm{C}$ in a humidified chamber with $5 \% \mathrm{CO}_{2}$. Cells were stimulated with HMGB1 (Sigma, St. Louis, MO, USA) for different intervals of $0,24,48$ and $72 \mathrm{~h}$ at a dose of $1,000 \mathrm{ng} / \mathrm{ml}$ which were named group $\mathrm{A}, \mathrm{B}, \mathrm{C}$ and $\mathrm{D}$, respectively; or at different doses of $0,10,100$ and $1,000 \mathrm{ng} / \mathrm{ml}$ for $48 \mathrm{~h}$ which were named group A', B', C' and D', respectively. In addition, we used BAY11-7082 (Cayman Chemical Co., Ann Arbor, MI, USA) to stimulate cells for $6 \mathrm{~h}$ and then stimulated the cells with HMGB1 for $48 \mathrm{~h}$ : a (control), b (only HMGB1), c (HMGB1+DMSO), d (BAY11-7082+HMGB1); we used anti-receptor for advanced glycation end products (RAGE) (BIOSS, Beijing, China) to stimulate the cells for $6 \mathrm{~h}$ and then stimulated cells with HMGB1 for 48 h: a' (control), b' (only HMGB1), c' (HMGB1+DMSO), and d' (anti-RAGE+HMGB1).

MTT assay. Analysis was performed using a 96-well plate; $1 \times 10^{5}$ cells in $200 \mu \mathrm{l}$ of DMEM/high glucose supplemented with $10 \%$ FBS were added to each well, and the cells were cultured for 24,48 and $72 \mathrm{~h}$ at $37^{\circ} \mathrm{C}$. After treating the cells with HMGB1, $20 \mu \mathrm{l}$ of MTT (Sigma) was added. The cells were then incubated for $4 \mathrm{~h}$ and optical densities were measured at $490 \mathrm{~nm}$.

Matrigel invasion analysis. Analysis was performed using a 24-well invasion chamber system which contained polycarbonate filters with a pore size of $8-\mu \mathrm{m}$ (Corning Costar, Inc.) with a Matrigel (Sigma) membrane. Each $500 \mu \mathrm{l}$ of DMEM/high glucose supplemented with $10 \%$ FBS was placed in the lower compartment of the chamber. In the pre-warmed and rehydrated upper compartment, $1 \times 10^{5}$ cells in $500 \mu \mathrm{l}$ of DMEM/high glucose supplemented without FBS were added, and the cells were allowed to migrate through the intermediate membrane for 24,48 and $72 \mathrm{~h}$ at $37^{\circ} \mathrm{C}$. The membranes were then fixed with neutral-buffered formalin and stained in hematoxylin and eosin staining. The cells that had attached to the lower side of the membrane were counted in ten highpowered fields (x400) under a microscope. Each experiment was repeated three times.

Quantitative real-time PCR. Quantitative real-time PCR was performed using the real-time PCR system 7300 (Applied Biosystems, Foster City, CA, USA). In brief, the PCR amplification reaction mixtures $(20 \mu \mathrm{l})$ contained cDNA, primer pairs, the dual-labeled fuorogenic probe, and TaqMan Universal PCR Master Mix (Takara Bio, Dalian, China).

The primers were: E-cadherin forward, 5'-AGAACGCAT TGCCACATACA-3' and reverse, 5'-TAAGCGATGGCGGCA TTGTA-3'; N-cadherin forward, 5'-CAACACACTCGCAGA CGCTCA-3' and reverse, 5'-AAGACGGCTCCAGGCAG TTT-3'; $\beta$-actin forward, 5'-CTTAGTTGCGTTACACCCTTT CTTG-3' and reverse, 5'-CTGTCACCTTCACCGTTCCAG TTT-3'.

PCRs were performed in triplicate. The relative fold changes were calculated with the following formula: $2^{-\Delta \Delta \mathrm{Ct}}$, $\Delta \mathrm{Ct}=\mathrm{Ct}$ (target) $-\mathrm{Ct}(\beta$-actin), which reflected the target gene expression normalized to $\beta$-actin levels. The fold increase or decrease in HMGB1 expression was determined for different groups and is expressed as mean \pm standard deviation (SD). 


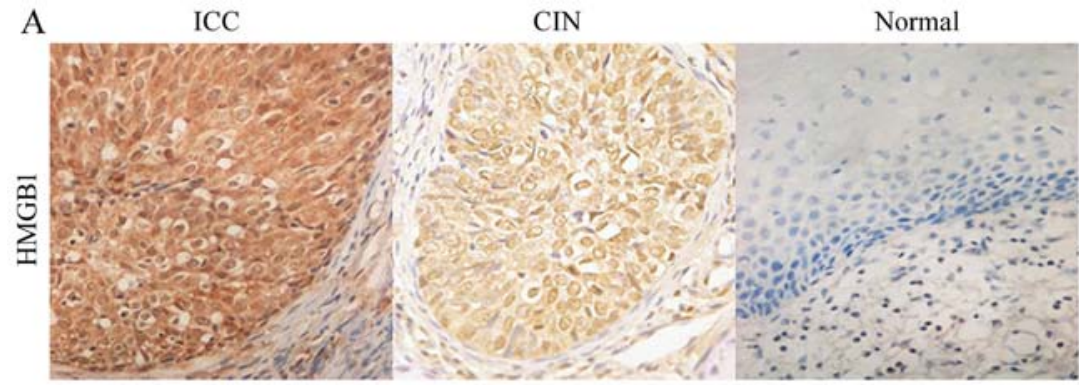

B
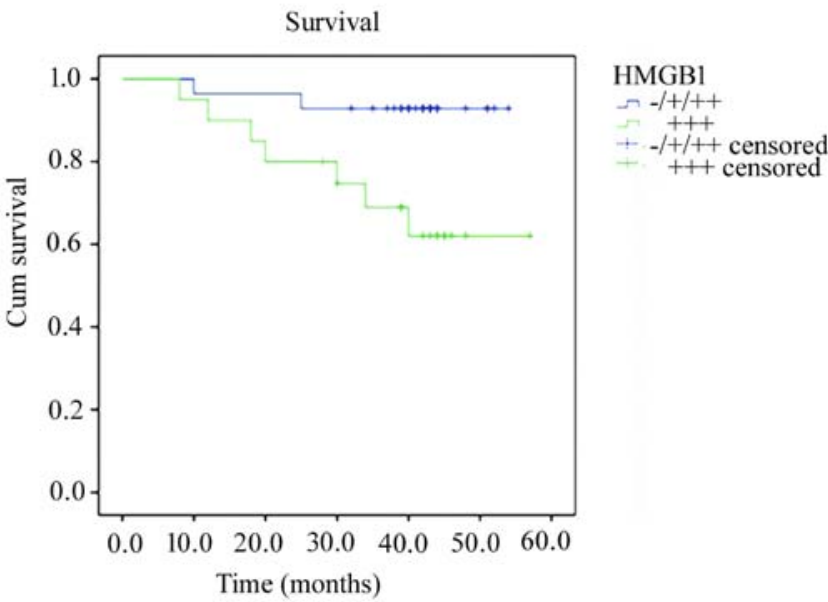

Figure 1. HMGB1 expression in cervical samples. (A) HMGB1 expression in different cervical samples. Image magnification, $\mathrm{x} 400$. (B) Kaplan-Meier survival curve of the cervical cancer patients according to HMGBI expression. HMGB1, high-mobility group box 1 protein; ICC, invasive cervical cancers; CIN, cervical intraepithelial neoplasia.

Western blot analysis. Proteins from the cell samples were extracted with RIPA buffer. Proteins were resolved via sodium dodecyl sulfate-polyacrylamide gel electrophoresis and blotted onto a nitrocellulose membrane. The membrane was incubated with the indicated primary anti-E-cadherin (1:500); anti-N-cadherin (1:500); anti-NF- $\mathrm{KB}$ (1:500); anti-IкB $(1: 500)$ and anti- $\beta$-actin $(1: 500)$, followed by incubation with anti-mouse and anti-rabbit immunoglobulin G. Protein expression was visualized using enhanced chemiluminescence. Comparison between different treatment groups was made by determining the specific protein/ $\beta$-actin ratio of the immunoreactive area with densitometry. Each experiment was repeated three times.

Statistical analysis. We analyzed all the statistics using SPSS 17.0 software (2009; SPSS, Inc., Chicago, IL, USA). Fisher's exact probability and Student's t-test were used for comparison between groups. Data are expressed as mean \pm SD and were analyzed with one-way and two-way ANOVA. We also used the Kaplan-Meier method to conduct the univariate overall survival analysis. Survival rate differences were performed with the log-rank test. Statistical significance was defined as $\mathrm{P}<0.05$.

\section{Results}

HMGB1 expression in cervical tissues and its clinical significance. HMGB1 was observed in carcinoma cell cytoplasm and nuclei, but was predominantly localized in the nuclei (Fig. 1A). The expression in the nuclei and cytoplasm was increased in the cancer tissues compared to that in the control tissues. Positive HMGB1 immunoreactivity was detected in $89.58 \%$ (43/48) of the cervical cancer cases, in $54.90 \%$ (28/51) of the CIN cases and $4.17 \%(1 / 24)$ of the control cases. Among the cancer cases, positive HMGB1 immunoreactivity was detected in $33.33 \%$ (16/48) of the FIGO stage I cases and $56.25 \%$ (27/48) of the FIGO stage II-III cases $(\mathrm{P}<0.05)$. In addition, HMGB1 protein was positively associated with lymph node metastasis and cell differentiation $(\mathrm{P}<0.05)$. However, there was no significant correlation between HMGB1 and age or histological type $(\mathrm{P}>0.05)$ (Table I). Kaplan-Meier analysis suggested that the mean survival time of cervical cancer cases with robust expression of HMGB1 was significantly lower (44.57 \pm 3.95 months) compared to the cervical cancer cases with weak or negative expression of HMGB1 (51.39 \pm 1.82 months) $(\mathrm{P}<0.05)$. In our results, patients strongly expressing HMGB1 had significantly greater rates of death than patients with weak expression $(\mathrm{P}<0.05, \log$-rank test) (Fig. 1B). These results suggest that HMGB1 may be a useful biomarker with which to evaluate clinical significance and outcome of cervical cancer.

Relationship between $H M G B 1, N F-\kappa B, E$-cadherin or $N$-cadherin. NF- $\mathrm{KB}$ staining was observed both in the cell cytoplasm and nuclei in the cervical cancer cases and control cases. However, in the cervical cancer cases, strong staining was mainly localized in the nuclei. NF- $\kappa B$ was significantly increased in cervical cancer samples compared to normal control samples (Fig. 2). We found that E-cadherin and N-cadherin were both located in the cytoplasm. E-cadherin expression was downregulated in cervical cancer tissues compared to that in 


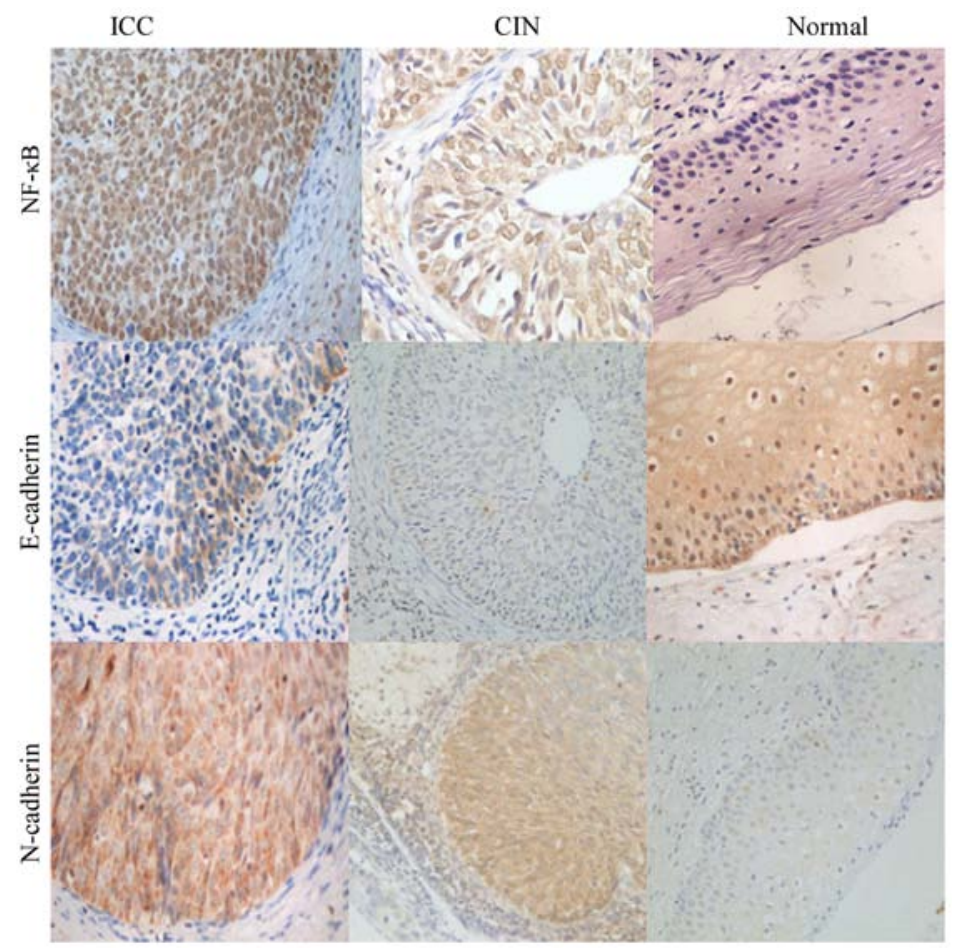

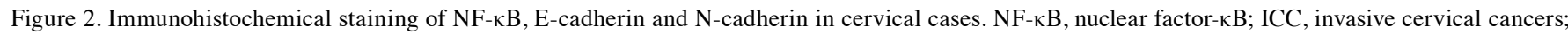
CIN, cervical intraepithelial neoplasia.

Table I. Expression of HMGB1 protein in cervical tissues and its relationship with clinicopathological factors.

\begin{tabular}{lrrrrrr}
\hline & & \multicolumn{3}{c}{ HMGB1 protein } & \\
\cline { 3 - 5 } $\begin{array}{l}\text { Clinicopathological } \\
\text { factors }\end{array}$ & $\mathrm{n}$ & - & + & ++ & +++ & P-value \\
\hline NSCES & 24 & 18 & 5 & 1 & 0 & \\
CIN & 51 & 2 & 21 & 28 & 0 & $<0.05$ \\
ICC & 48 & 2 & 3 & 23 & 20 & \\
Age (years) & & & & & & 0.93 \\
$\quad$ <45 & 19 & 1 & 1 & 10 & 7 & \\
$\geq 45$ & 29 & 1 & 2 & 13 & 13 & \\
FIGO & & & & & & $<0.05$ \\
I & 21 & 2 & 3 & 15 & 1 & \\
II-III & 27 & 0 & 0 & 8 & 19 & \\
Histological type & & & & & & 0.55 \\
$\quad$ SCC & 41 & 2 & 3 & 18 & 18 & \\
$\quad$ ADC & 7 & 0 & 0 & 5 & 2 & \\
Differentiation & & & & & & 0.03 \\
$\quad$ Well & 8 & 2 & 1 & 3 & 2 & \\
$\quad$ Moderate & 32 & 0 & 2 & 14 & 16 & \\
$\quad$ Poor & 8 & 0 & 0 & 6 & 2 & \\
LN metastasis & & & & & & 0.01 \\
$\quad$ Positive & 14 & 0 & 0 & 3 & 11 & \\
$\quad$ Negative & 34 & 2 & 3 & 20 & 9 & \\
\hline
\end{tabular}

HMGB1, high-mobility group box 1 protein; NSCES, normal squamous epithelial specimens; CIN, cervical intraepithelial neoplasia; ICC, invasive cervical cancers; LN, lymph node; SCC, squamous cell carcinoma; ADC, adenocarcinoma. the normal tissues (Fig. 2), on the contrary, N-cadherin expression was upregulated in cervical cancer tissues compared to normal tissues (Fig. 2). According to the immunohistochemistry results, we found that both HMGB1 and NF- $\kappa B$ showed strong staining in the nuclei in cervical cancer cases, and we found that HMGB1 expression was positively associated with $\mathrm{NF}-\kappa \mathrm{B}$ and $\mathrm{N}$-cadherin $(\mathrm{r}=0.76 ; \mathrm{r}=0.69$, both $\mathrm{P}<0.05)$; we also found that E-cadherin expression was negatively associated with HMGB1 ( $\mathrm{r}=-0.68, \mathrm{P}<0.05)$ (Table II).

HMGB1 promotes morphological changes in HeLa cells. Morphological observations of a normal control group of HeLa cells indicated that cells were epithelial, polygonal, with close cell-cell junctions, and growing in clusters. After stimulation with $1,000 \mathrm{ng} / \mathrm{ml}$ HMGB1 for $72 \mathrm{~h}$, the HeLa cells had sparse cell-cell junctions, became spindle-shaped, and exhibited a disappearance of polarity. After treatment with HMGB1, the HeLa cells transitioned from an epithelial morphology into a mesenchymal morphology. This was similar to the morphological changes that occur after EMT (Fig. 3A).

HMGB1 promotes proliferation and invasion of HeLa cells. The MTT cell proliferation assay indicated that treatment with $1,000 \mathrm{ng} / \mathrm{ml}$ HMGB1 for $48 \mathrm{~h}$ significantly increased the culture optical density (OD) compared to that of the control group ( $2.82 \pm 0.03$ vs. $1.60 \pm 0.06)$. This treatment had the greatest positive effect on cell proliferation of all tested treatments (Table III). In the Transwell assay, we observed that the number of penetrated cells in group D $(1,000 \mathrm{ng} / \mathrm{ml}$ HMGB1 for $72 \mathrm{~h}$ ) was significantly higher than that in group A $(1,000 \mathrm{ng} / \mathrm{ml}$ HMGB1 for 0 h) $(345.20 \pm 28.90$ vs. $6.20 \pm 2.28)$, and the number of penetrated cells in group D' $(1,000 \mathrm{ng} / \mathrm{ml}$ HMGB1 for $72 \mathrm{~h}$ ) was evidently higher than that in group A' 
Table II. Association between HMGB1 and NF-кB, E-cadherin and N-cadherin expression in the cervical samples.

\begin{tabular}{|c|c|c|c|c|c|c|c|c|c|c|c|c|c|c|}
\hline \multicolumn{4}{|c|}{$\mathrm{NF}-\kappa \mathrm{B}$} & \multicolumn{5}{|c|}{ N-cadherin } & \multirow[b]{2}{*}{ P-value } & \multicolumn{4}{|c|}{ E-cadherin } & \\
\hline- & + & ++ & +++ & P-value & - & + & ++ & +++ & & - & + & ++ & +++ & P-value \\
\hline
\end{tabular}

\begin{tabular}{|c|c|c|c|c|c|c|c|c|c|c|c|c|c|c|c|}
\hline \multicolumn{16}{|c|}{ HMGB1 } \\
\hline- & 17 & 2 & 3 & 0 & $<0.05$ & 14 & 7 & 1 & 0 & $<0.05$ & 1 & 3 & 4 & 14 & $<0.05$ \\
\hline+ & 5 & 15 & 9 & 0 & & 6 & 9 & 13 & 1 & & 2 & 3 & 14 & 10 & \\
\hline++ & 0 & 13 & 30 & 9 & & 1 & 9 & 30 & 12 & & 21 & 22 & 9 & 0 & \\
\hline+++ & 0 & 0 & 4 & 16 & & 0 & 2 & 4 & 14 & & 15 & 3 & 1 & 1 & \\
\hline \multicolumn{6}{|c|}{$r=0.76$} & \multicolumn{4}{|c|}{$r=0.69$} & \multicolumn{6}{|c|}{$r=-0.68$} \\
\hline
\end{tabular}

HMGB1, high-mobility group box 1 protein; NF- $\kappa B$, nuclear factor- $\kappa \mathrm{B}$.

A

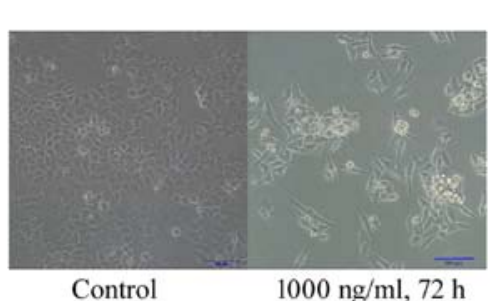

$\mathrm{C}$

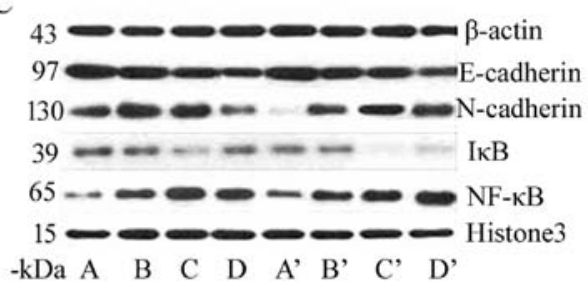

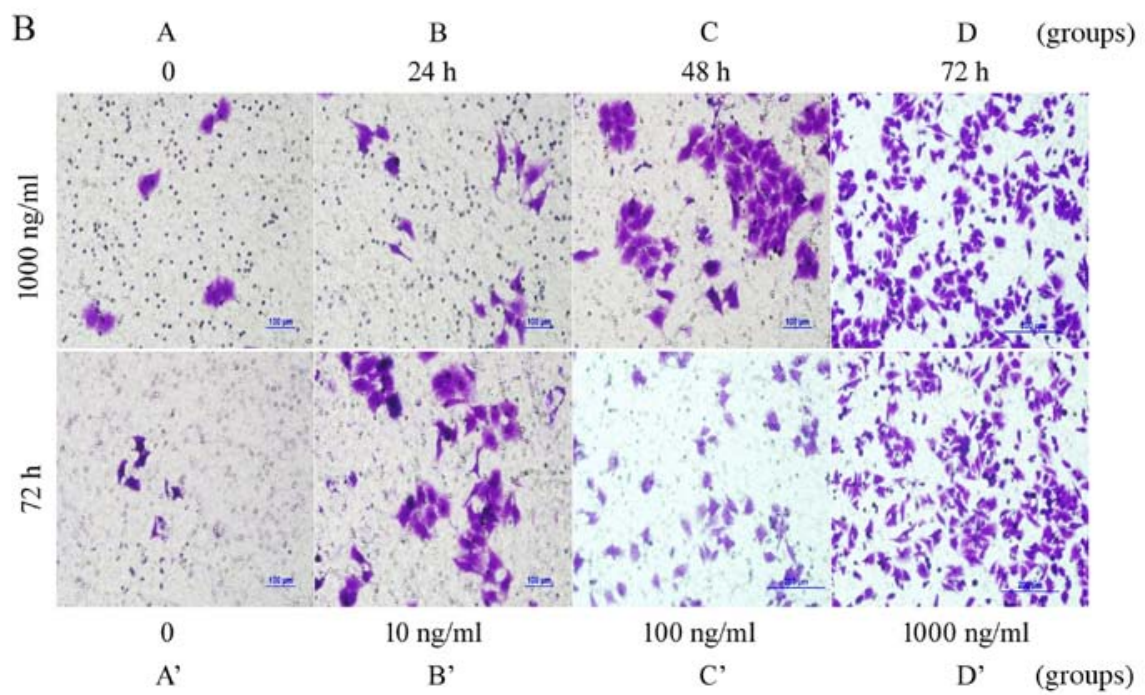

Figure 3. Biological behavior of HeLa cells after stimulation by high-mobility group box 1 protein (HMGB1). (A) HeLa cell morphological changes. (B) Transwell assay following HMGB1 stimulation. (C) Expression of E-cadherin, N-cadherin, nuclear factor- $\kappa \mathrm{B}(\mathrm{NF}-\kappa \mathrm{B})$ and inhibitor $\kappa \mathrm{B}$ (I $\kappa \mathrm{B})$ protein in HeLa cells by western blot analysis. Groups: A, cells were stimulated with HMGB1 for $0 \mathrm{~h}$ at a dose of 1,000 ng/ml; B, cells were stimulated with HMGB1 for $24 \mathrm{~h}$ at a dose of $1,000 \mathrm{ng} / \mathrm{ml} ; \mathrm{C}$, cells were stimulated with HMGB1 for $48 \mathrm{~h}$ at a dose of 1,000 ng/ml; D, cells were stimulated with HMGB1 for $72 \mathrm{~h}$ at a dose of $1,000 \mathrm{ng} /$ ml. Groups: A', at a dose of $0 \mathrm{ng} / \mathrm{ml}$ for $48 \mathrm{~h}$; B', at a dose of $10 \mathrm{ng} / \mathrm{ml}$ for $48 \mathrm{~h}$; C', at a dose of $100 \mathrm{ng} / \mathrm{ml}$ for $48 \mathrm{~h}$; and D', at a dose of $1,000 \mathrm{ng} / \mathrm{ml}$ for $48 \mathrm{~h}$.

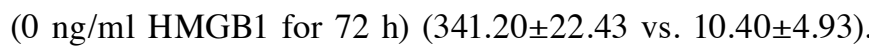
These results suggested that stimulation with $1,000 \mathrm{ng} / \mathrm{ml}$ HMGB1 for $72 \mathrm{~h}$ had the greatest positive effect in enhancing cell invasiveness (Table IV and Fig. 3B). These results demonstrated that HMGB1 overexpression enhanced tumor migration and invasion in vitro.

HMGB1 promotes mesenchymal marker expression and reduces epithelial marker expression in cervical cancer cells. Western blot analysis showed that treatment with $1,000 \mathrm{ng} / \mathrm{ml}$ HMGB1 for $48 \mathrm{~h}$ significantly reduced cytoplasmic E-cadherin and $\mathrm{I} \kappa \mathrm{B}$ expression levels, markedly increased cytoplasmic
$\mathrm{N}$-cadherin expression levels, and significantly increased nuclear NF- $\kappa \mathrm{B}$ expression levels (Fig. 3C). These results indicated that HMGB1 stimulation reduced the expression levels of epithelial markers on the surface of HeLa cells, whereas that of mesenchymal markers was increased, which indicates EMT. Reduced I $\mathrm{B}$ expression in the cytoplasm and increased $\mathrm{NF}-\kappa \mathrm{B}$ expression in the nucleus suggested that $\mathrm{NF}-\kappa \mathrm{B}$ may be activated. Similar results were obtained by performing real-time PCR. The relative expression level of N-cadherin mRNA in group C $(1,000 \mathrm{ng} / \mathrm{ml}$ HMGB1 for $48 \mathrm{~h}$ ) was $1.00 \pm 0.05$, which was higher than that in group $\mathrm{A}$ $(1,000 \mathrm{ng} / \mathrm{ml} \mathrm{HMGB} 1$ for $0 \mathrm{~h})(0.27 \pm 0.02)$. The relative 
Table III. Proliferation ability of HeLa cells after HMGB1 stimulation.

\begin{tabular}{lccc}
\hline & \multicolumn{3}{c}{ OD value } \\
\cline { 2 - 4 } $\begin{array}{l}\text { HMGB1 } \\
\text { stimulation }\end{array}$ & $24 \mathrm{~h}$ & $48 \mathrm{~h}$ & $72 \mathrm{~h}$ \\
\hline 0 & $0.81 \pm 0.02$ & $1.60 \pm 0.06$ & $1.43 \pm 0.03$ \\
$10 \mathrm{ng} / \mathrm{ml}$ & $1.02 \pm 0.11$ & $2.06 \pm 0.07$ & $1.50 \pm 0.02$ \\
$100 \mathrm{ng} / \mathrm{ml}$ & $1.73 \pm 0.04$ & $2.45 \pm 0.07$ & $1.99 \pm 0.10$ \\
$1,000 \mathrm{ng} / \mathrm{ml}$ & $1.91 \pm 0.02$ & $2.82 \pm 0.03$ & $2.21 \pm 0.03$ \\
\hline
\end{tabular}

HMGB1, high-mobility group box 1 protein; OD, optical density.

expression level of E-cadherin mRNA in group $\mathrm{C}$ was $0.80 \pm 0.04$, which was lower than that in group A $(1,000 \mathrm{ng} / \mathrm{ml}$ HMGB1 for $0 \mathrm{~h})(1.00 \pm 0.04)$. The relative expression level of $\mathrm{N}$-cadherin mRNA in group D' (1,000 ng/ml HMGB1 for $48 \mathrm{~h})$ was $0.93 \pm 0.05$, which was higher than that in group $A^{\prime}(0 \mathrm{ng} / \mathrm{ml}$ HMGB1 for $48 \mathrm{~h})(0.46 \pm 0.06)$. The relative expression level of E-cadherin mRNA was $0.64 \pm 0.02$, which was lower than that of group A' (0 ng/ml HMGB1 for 48 h) $(0.98 \pm 0.06)$ (Table V).

Treatment with $N F-\kappa B$ inhibitor and RAGE antagonist reduces HMGBI-mediated HeLa cell proliferation and metastasis. For this study, HeLa cells were treated with NF- $\kappa \mathrm{B}$ inhibitor BAY11-7082 and anti-RAGE, and then stimulated with 1,000 ng/ml HMGB1 for 48 or $72 \mathrm{~h}$. The results of MTT assays showed that cell proliferation (OD) in group d was significantly lower than that in group b $(2.04 \pm 0.07$ vs. $2.46 \pm 0.09)$, and the OD in group d' was evidently lower than that in group b' $(1.70 \pm 0.07$ vs. $2.67 \pm 0.05)$. These observations indicated that inhibition of the $\mathrm{NF}-\kappa \mathrm{B}$ pathway significantly attenuated HMGB1-mediated stimulation of HeLa cells (Table VI). After $72 \mathrm{~h}$ of HMGB1 stimulation, the Transwell assay indicated that the number of penetrated cells in group d was significantly lower than that in group b $(102.40 \pm 8.20$ vs. $290.40 \pm 11.33)$, and the number of penetrated cells in group d' was evidently lower than that in group b' $(86.80 \pm 6.14$ vs. $293.00 \pm 15.60)$ (Table VII and Fig. 4A). These results suggested that HMGB1 may cause the morphological and biological changes observed in HeLa cells by activating the NF- $\kappa \mathrm{B}$ signaling pathway.

Treatment with $N F-\kappa B$ inhibitor and RAGE antagonist reduces HMGBl-mediated EMT in HeLa cells. For this study, HeLa cells were treated with NF- $\mathrm{B}$ inhibitor BAY11-7082 and anti-RAGE, and then stimulated with 1,000 $\mathrm{ng} / \mathrm{ml}$ HMGB1 for $48 \mathrm{~h}$. Western blot analysis showed that the level of E-cadherin expression in the cytoplasm in group d with the addition of BAY11-7082 was higher than that in group b, $\mathrm{N}$-cadherin expression levels in the cytoplasm were markedly reduced, and $\mathrm{I} \kappa \mathrm{B}$ expression levels in the cytoplasm were increased. The level of NF- $\kappa \mathrm{B}$ expression in the nucleus was decreased. Similar changes also were observed in group d' with the addition of anti-RAGE (Fig. 4B). These results were consistent with those of real-time PCR assays. The relative expression level of $\mathrm{N}$-cadherin $\mathrm{mRNA}$ in group $\mathrm{d}$ was $2.05 \pm 0.16$, which was lower than that in group b $(3.72 \pm 0.08)$,

Table IV. Invasion ability of HeLa cells after HMGB1 stimulation.

No. of invasive HeLa cells

\begin{tabular}{|c|c|c|c|c|c|c|c|c|}
\hline \multirow{3}{*}{ Groups } & \multicolumn{4}{|c|}{ HMGB 1 at $1,000 \mathrm{ng} / \mathrm{ml}$ (different intervals) } & \multicolumn{4}{|c|}{ HMGB1 for $72 \mathrm{~h}$ (different doses) } \\
\hline & A & $\mathrm{B}$ & $\mathrm{C}$ & $\mathrm{D}$ & $A^{\prime}$ & $\mathrm{B}^{\prime}$ & $C^{\prime}$ & $\mathrm{D}^{\prime}$ \\
\hline & 0 & $24 \mathrm{~h}$ & $48 \mathrm{~h}$ & $72 \mathrm{~h}$ & 0 & $10 \mathrm{ng} / \mathrm{ml}$ & $100 \mathrm{ng} / \mathrm{ml}$ & $1,000 \mathrm{ng} / \mathrm{ml}$ \\
\hline No. & $6.20 \pm 2.28$ & $23.20 \pm 3.70$ & $72.60 \pm 4.83$ & $345.20 \pm 28.90$ & $10.40 \pm 4.93$ & $57.00 \pm 6.89$ & $74.60 \pm 6.88$ & $341.20 \pm 22.43$ \\
\hline
\end{tabular}

Table V. mRNA expression of E-cadherin and N-cadherin in the HeLa cells after HMGB1 stimulation.

mRNA (mean \pm SD)

\begin{tabular}{|c|c|c|c|c|c|c|c|c|}
\hline \multirow{3}{*}{ Groups } & \multicolumn{4}{|c|}{ HMGB1 $(1,000 \mathrm{ng} / \mathrm{ml})$} & \multicolumn{4}{|c|}{ HMGB1 (48 h) } \\
\hline & A & B & $\mathrm{C}$ & $\mathrm{D}$ & $A^{\prime}$ & $\mathrm{B}^{\prime}$ & $\mathrm{C}^{\prime}$ & $D^{\prime}$ \\
\hline & 0 & $24 \mathrm{~h}$ & $48 \mathrm{~h}$ & $72 \mathrm{~h}$ & 0 & $10 \mathrm{ng} / \mathrm{ml}$ & $100 \mathrm{ng} / \mathrm{ml}$ & $1,000 \mathrm{ng} / \mathrm{ml}$ \\
\hline E-cad & $1.00 \pm 0.04$ & $0.85 \pm 0.06$ & $0.80 \pm 0.04$ & $1.05 \pm 0.03$ & $0.98 \pm 0.06$ & $1.09 \pm 0.03$ & $0.90 \pm 0.04$ & $0.64 \pm 0.02$ \\
\hline N-cad & $0.27 \pm 0.02$ & $0.49 \pm 0.03$ & $1.00 \pm 0.05$ & $0.59 \pm 0.02$ & $0.46 \pm 0.06$ & $0.59 \pm 0.01$ & $1.05 \pm 0.09$ & $0.93 \pm 0.05$ \\
\hline
\end{tabular}

HMGB1, high-mobility group box 1 protein. Groups: A, cells were stimulated with HMGB1 for $0 \mathrm{~h}$ at a dose of 1,000 ng/ml; B, cells were stimulated with HMGB1 for $24 \mathrm{~h}$ at a dose of $1,000 \mathrm{ng} / \mathrm{ml}$; C, cells were stimulated with HMGB1 for $48 \mathrm{~h}$ at a dose of 1,000 ng/ml; D, cells were stimulated with HMGB1 for $72 \mathrm{~h}$ at a dose of 1,000 ng/ml. Groups: A', at a dose of $0 \mathrm{ng} / \mathrm{ml} \mathrm{for} 48 \mathrm{~h}$; B', at a dose of $10 \mathrm{ng} / \mathrm{ml}$ for $48 \mathrm{~h}$; C', at a dose of $100 \mathrm{ng} / \mathrm{ml}$ for $48 \mathrm{~h}$; and D', at a dose of 1,000 ng/ml for $48 \mathrm{~h}$. 


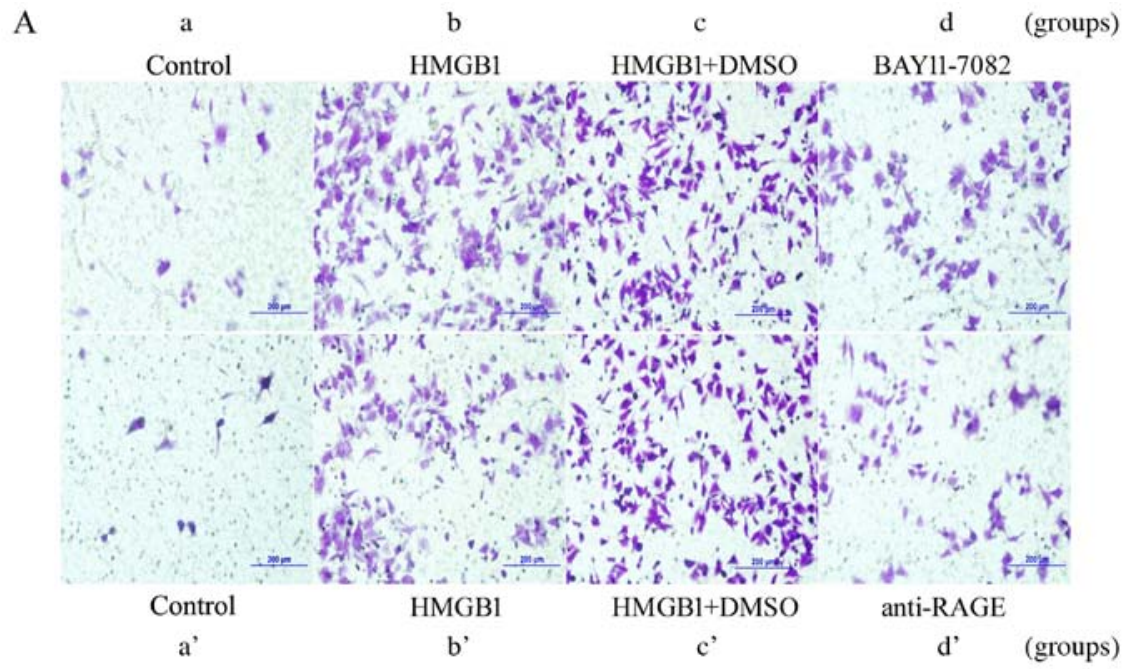

B

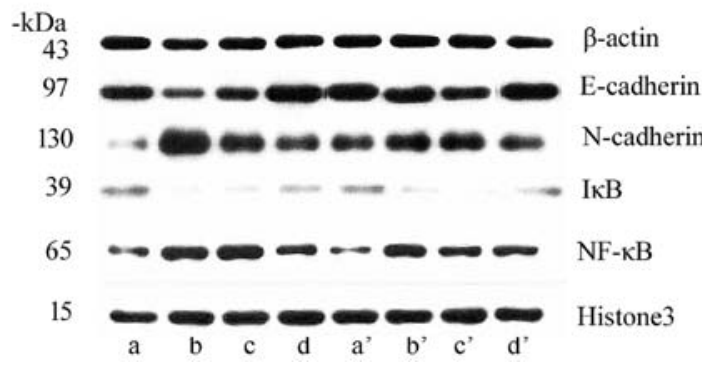

Figure 4. Biological behavior of HeLa cells after stimulation with high-mobility group box 1 protein (HMGB1) when using BAY11-7082 or anti-receptor for advanced glycation end products (RAGE). (A) Transwell assay. (B) Expression of E-cadherin, N-cadherin, nuclear factor- $\kappa \mathrm{B}$ (NF- $\kappa \mathrm{B})$ and inhibitor $\kappa \mathrm{B}$ (IאB) protein in HeLa cells treated with BAY11-7082 or anti-RAGE by western blot analysis. Groups: a, control; b, cells cultured with HMGB1 at a dose of $1,000 \mathrm{ng} / \mathrm{ml}$ for $48 \mathrm{~h}$; c, cells cultured with DMSO for $6 \mathrm{~h}$ and then stimulated the cells with HMGB1 for $48 \mathrm{~h}$; and d, cells cultured with BAY11-7082 for $6 \mathrm{~h}$ and then stimulated the cells with HMGB1 for $48 \mathrm{~h}$. Groups: a', control; b', cells cultured with HMGB1 at a dose of 1,000 ng/ml for $48 \mathrm{~h}$; c', cells cultured with DMSO for $6 \mathrm{~h}$ and then stimulated the cells with HMGB1 for $48 \mathrm{~h}$; and d', cells cultured with advanced glycation end products (RAGE) for $6 \mathrm{~h}$ and then stimulated the cells with HMGB1 for $48 \mathrm{~h}$.

cervical cancer is a major threat to the health and life of women (6). The current treatment for cervical cancer is the comprehensive therapy of surgery (dominant) + radiochemotherapy (adjuvant) (7). Surgical treatment has a critical role in patient prognosis, and cervical cancer metastasis has adverse consequences for patient treatment and prognosis. Therefore, early diagnosis and treatment are crucial. However, the primary mechanism of cervical cancer metastasis is unknown.

There are many causes and mechanisms for the invasion and metastasis of cervical cancer, and EMT is believed to play an important role. EMT is a physiological phenomenon in mammalian fetal development, and loss of epithelial cell polarity and acquisition of mesenchymal properties has important roles in tumor invasion and metastasis $(8,9)$. The significant features of EMT are the decrease or loss of E-cadherin and the upregulation of transcription factors such as $\mathrm{N}$-cadherin, Snail, Twist, and the zinc finger E-box-binding protein 1/2 (ZEB1/2) (10-12). Normal epithelial cells have typical apical-basal polarity, close cell-cell junctions, and are adherent to basal cells, all of which limit cell migration capacity. During tumor proliferation and metastasis, normal epithelial cells undergo a series of changes, including the loss of epithelial cell polarity, acquisition of mesenchymal properties, loss of close cell-cell junctions and adhesion, and acquisition of free migration capability. These changes enable tumor cells to metastasize locally at the primary lesion, or metastasize via blood vessels, lymphatic vessels, and other pathways; these changes have important roles in tumor invasion and metastasis $(13,14)$. In clinical specimens of cervical cancer, Lee et al observed that expression of the EMT marker E-cadherin was reduced, whereas that of vimentin was increased. After treatment with endothelial growth factor (EGF), cervical cancer cells demonstrated morphological changes including a fusiform, spindle-shaped fibroblastic morphology, an enlarged intercellular space, and increased migration and invasion capabilities (15).

In a resting state, NF- $\mathrm{\kappa B}$ binds with its inhibitory protein $\mathrm{I} \kappa \mathrm{B}$ and is present in the cytoplasm in an inactivated form. During cell stimulation, cytoplasmic I $\mathrm{KB}$ is phosphorylated and degraded, which causes NF- $\kappa \mathrm{B}$ release. Free NF- $\kappa \mathrm{B}$ is then able to enter into the nucleus, where it regulates the transcription and expression of several genes that are involved in the EMT process of tumors (16). NF- $\mathrm{KB}$ is a key factor that stimulates transforming growth factor $\beta$ (TGF- $\beta$ )-induced EMT. NF- $\kappa B$ inhibition can block TGF- $\beta$-induced EMT of breast epithelial cells, whereas NF- $\mathrm{BB}$ activation can promote mesenchymal cell morphology (17). A recent study reported that NF- $\mathrm{kB}$ could suppress E-cadherin protein expression by promoting Snail expression (18). These results indicate that $\mathrm{NF}-\mathrm{\kappa B}$ activation has a crucial role in EMT of tumor cells, and contributes to the development of tumor metastasis. 
It is widely reported that HMGB1 can act as a cytokine or a growth factor that promotes extracellular signal transmission by binding with the corresponding cell surface receptors, and thereby participates in tumor invasion and metastasis (19). Several roles of HMGB1 have been reported. HMGB1 plays an important role in various diseases, from autoimmune diseases and tumors to ischemia-reperfusion injury and shock; HMGB1 is also closely related to the development of prostatic, breast, pancreatic, and intestinal cancer $(20,21)$. Our results showed that HMGB1 expression in cervical carcinoma tissues was significantly increased, was positively correlated with the grade of the lesion, and was closely associated with invasion, lymph node metastasis, clinical staging and outcomes. Therefore, HMGB1 expression could be used as an important indicator for invasion, metastasis, and prognosis of cervical carcinoma. In order to further explore the mechanism of HMGB1 in invasive cancer, we analyzed the expression of $\mathrm{NF}-\kappa \mathrm{B}$ and E-cadherin that were involved in the pathway of $\mathrm{NF}-\kappa \mathrm{B}$ signaling. Studies have shown that nuclear expression of $\mathrm{NF}-\kappa \mathrm{B}$ is increased in carcinoma groups. HMGB1 was positively correlated with $\mathrm{NF}-\kappa \mathrm{B}$ expression and co-expressed in the cell nuclei, which we observed in serial sections of cervical tissues indicating it may activate $\mathrm{NF}-\kappa \mathrm{B}$ signaling through some mechanism mediated by HMGB1. HMGB1 causes phosphorylation, ubiquitylation and degradation of $\mathrm{I} \kappa \mathrm{B}$ so that I $\kappa$ B combining with $\mathrm{NF}-\kappa \mathrm{B}$ was decreased. HMGB1 may initiate the process of $\mathrm{NF}-\kappa \mathrm{B}$ translocation to the nuclei. We also found that HMGB1 and E-cadherin were negatively related; HMGB1 and $\mathrm{N}$-cadherin were positively related, which indicates that $\mathrm{HMGB} 1$ may activate $\mathrm{NF}-\kappa \mathrm{B}$ via binding the receptor leading to a change in the relative downstream target genes, which result in EMT of cervical cancer. The specific mechanism needs to be further studied using cervical cancer cell lines in vitro. Our results showed that HMGB1mediated stimulation of HeLa cells caused morphological changes (polygonal, epithelial-to-fusiform, and spindle-shaped transitions), significantly increased the intercellular space, reduced cell adhesion, and promoted free cell migration. HMGB1 stimulation of HeLa cells increased cell proliferation and invasion compared to that of the control group. Western blot analysis and real-time PCR analyses showed a significant increase in protein and mRNA levels of the mesenchymal marker $\mathrm{N}$-cadherin on the HeLa cell surface, but a significant reduction in protein and mRNA levels of the epithelial marker E-cadherin. These effects were maximized by treatment with $1,000 \mathrm{ng} / \mathrm{ml}$ HMGB1 for $48 \mathrm{~h}$.

HMGB1 can bind RAGE and stimulate the MAPK and $\mathrm{NF}-\kappa \mathrm{B}$ signaling pathways (22). HMGB1 has a high affinity for RAGE, which is 7 times greater than the binding affinity of other RAGE ligands. The binding of HMGB1 and RAGE can activate NF- $\kappa \mathrm{B}$ nuclear translocation and MAPK pathway signaling, thereby inducing macrophages to express inflammatory and chemotactic factors, and stimulating vascular endothelial cells to express adhesion molecules (23-25). During the transition of renal tubular epithelial cells to renal fibrotic cells, HMGB1 has an important role in regulating the occurrence of EMT as an intermediate (26). A study of a mouse pulmonary fibrosis model reported that HMGB1 bound RAGE, caused an increase in TGF- $\beta$, and promoted the transition from alveolar type II epithelial cells to mesenchymal cells (i.e., EMT) (27). In the present study, HMGB1-mediated cell stimulation was attenuated by the addition of anti-RAGE; the expression of $\mathrm{N}$-cadherin was decreased compared to that without anti-RAGE treatment. This suggested that addition of anti-RAGE blocked the EMT phenomenon which was caused by HMGB1. These results indicate that anti-RAGE competitively bound with RAGE, which suppressed extracellular HMGB1 binding with RAGE and its tumor-promoting effect. We propose that RAGE antagonism therapy may become a new target for cervical cancer treatment.

$\mathrm{NF}-\kappa \mathrm{B}$ is a nuclear factor that is present in many cells. It participates in the regulation of several genes involved in inflammation, immune reactions, cell proliferation and apoptosis. RAGE-bound HMGB1 can activate extracellular signal-regulated kinase (ERK) $1 / 2$ and p38MAPK. The primary mechanism is that HMGB1 binding to RAGE facilitates I $\mathrm{B}$ phosphorylation and degradation and suppresses $\mathrm{NF}-\kappa \mathrm{B}$ inhibition, which activates $\mathrm{NF}-\kappa \mathrm{B}$ (28), thereby promoting tumor occurrence, development, and metastasis. HMGB1 and Toll-like receptor (TLR) binding can upregulate $N F-\kappa B$ expression and promote $N F-\kappa B$ activation. Ligandbinding TLR4 and TLR 2 contribute to their own dimerization and their binding with the connexin MyD88, and activate $\mathrm{NF}-\kappa \mathrm{B}$ and MAPK signaling pathways by activating downstream interleukin receptor-associated kinase (IRAK) and TNF receptor-associated factor 6 (TRAF6) $(29,30)$. In the resting state, $\mathrm{NF}-\kappa \mathrm{B}$ binds with its inhibitory protein $\mathrm{I} \kappa \mathrm{B}$ and is present in the cytoplasm in an inactivated form. During cell stimulation, cytoplasmic I $\mathrm{B}$ B is phosphorylated and degraded, which relieves $\mathrm{NF}-\kappa \mathrm{B}$ inhibition and enables $\mathrm{NF}-\kappa \mathrm{B}$ entry into the nucleus. Therefore, $N F-\kappa B$ activation has a crucial role in EMT of tumor cells and contributes to tumor development and metastasis.

We hypothesized that HMGB1 could activate NF- $\kappa \mathrm{B}$ and MAPK signaling pathways, cause EMT in cervical cells, and thereby promote cervical cancer metastasis. This study showed that HMGB1-mediated stimulation of HeLa cells significantly increased $\mathrm{NF}-\kappa \mathrm{B}$ protein expression levels in the nucleus, whereas the expression level of $\mathrm{I} \kappa \mathrm{B}$ in the cytoplasm declined, indicating that HMGB1 promoted NF- $\kappa \mathrm{B}$ activation after stimulation of the HeLa cells. Suppression of NF- $\kappa \mathrm{B}$ pathway activation also suppressed HMGB1-mediated EMT in HeLa cells, reduced HeLa cell proliferation and invasion capabilities, reduced $\mathrm{N}$-cadherin protein levels on the HeLa cell surface, and increased E-cadherin protein and mRNA levels. These results suggest that HMGB1 may contribute to the invasion and migration of cervical cancer cells by activating the NF- $\kappa \mathrm{B} / \mathrm{I} \kappa \mathrm{B}$ signaling pathway, and thus cause local invasion and distant metastasis.

These combined results suggest that HMGB1 may promote the invasion and migration of cervical cancer cells by activating $\mathrm{NF}-\kappa \mathrm{B}$ signaling. However, tumor invasion and metastasis is a complex process that requires many factors and multiple steps. EMT is one of the initiating factors that cause tumor metastasis, and many signaling pathways are involved in EMT regulation. Further studies are required to investigate the role of HMGB1 in EMT regulation during cervical cancer metastasis, which will clarify the mechanism of cervical cancer metastasis, improve the diagnosis of cervical cancer, and discover new therapeutic treatments. 


\section{Acknowledgements}

This study was supported by the National Natural Science Foundation of China (grant no. 81372776), the Youth Project of National Natural Science Foundation (grant no. 81202048), the Higher Specialized Research Fund for the Doctoral Program (grant no. 20122104110014), and the Free Researcher Project of Shengjing Hospital (grant no. 201302).

\section{References}

1. Lee MY and Shen MR: Epithelial-mesenchymal transition in cervical carcinoma. Am J Transl Res 4: 1-13, 2012.

2. Iwatsuki M, Mimori K, Yokobori T, Ishi H, Beppu T, Nakamori S, Baba $\mathrm{H}$ and Mori M: Epithelial-mesenchymal transition in cancer development and its clinical significance. Cancer Sci 101: 293-299, 2010.

3. Chen RC, Yi PP, Zhou RR, Xiao MF, Huang ZB, Tang DL, Huang $Y$ and Fan XG: The role of HMGB1-RAGE axis in migration and invasion of hepatocellular carcinoma cell lines. Mol Cell Biochem 390: 271-280, 2014.

4. Evans A, Lennard TW and Davies BR: High-mobility group protein 1(Y): Metastasis-associated or metastasis-inducing? J Surg Oncol 88: 86-99, 2004.

5. Chen XY and Yuan R: Expression and significance of HMGB1 and E-cadherin in ovarian carcinoma. J Chongqing Med Univ 37: 614-616, 2012 (In Chinese).

6. Zhao FH, Tiggelaar SM, Hu SY, Xu LN, Hong Y, Niyazi M, Gao XH, Ju LR, Zhang LQ, Feng XX, et al: A multi-center survey of age of sexual debut and sexual behavior in Chinese women: Suggestions for optimal age of human papillomavirus vaccination in China. Cancer Epidemiol 36: 384-390, 2012.

7. Jemal A, Bray F, Center MM, Ferlay J, Ward E and Forman D: Global cancer statistics. CA Cancer J Clin 61: 69-90, 2011.

8. López-Novoa JM and Nieto MA: Inflammation and EMT: An alliance towards organ fibrosis and cancer progression. EMBO Mol Med 1: 303-314, 2009

9. Savagner P: The epithelial-mesenchymal transition (EMT) phenomenon. Ann Oncol 21 (Suppl 7): vii89-vii92, 2010.

10. Wu ST, Sun GH, Hsu CY, Huang CS, Wu YH, Wang HH and Sun KH: Tumor necrosis factor- $\alpha$ induces epithelial-mesenchymal transition of renal cell carcinoma cells via a nuclear factor kappa B-independent mechanism. Exp Biol Med (Maywood) 236: 1022-1029, 2011.

11. Li CW, Xia W, Huo L, Lim SO, Wu Y, Hsu JL, Chao CH, Yamaguchi H, Yang NK, Ding Q, et al: Epithelial-mesenchymal transition induced by TNF- $\alpha$ requires NF- $\kappa \mathrm{B}$-mediated transcriptional upregulation of Twist1. Cancer Res 72: 1290-1300, 2012.

12. Chua HL, Bhat-Nakshatri P, Clare SE, Morimiya A, Badve S and Nakshatri H: NF-kappaB represses E-cadherin expression and enhances epithelial to mesenchymal transition of mammary epithelial cells: Potential involvement of ZEB-1 and ZEB-2. Oncogene 26: 711-724, 2007.

13. Wang SC, Lin XL, Wang HY, Qin YJ, Chen L, Li J, Jia JS, Shen HF, Yang S, Xie RY, et al: Hes1 triggers epithelial-mesenchymal transition (EMT)-like cellular marker alterations and promotes invasion and metastasis of nasopharyngeal carcinoma by activating the PTEN/AKT pathway. Oncotarget 6: 36713-36730, 2015.

14. Lin Z, Li W, Zhang H, Wu W, Peng Y, Zeng Y, Wan Y, Wang J and Ouyang N: CCL18/PITPNM3 enhances migration, invasion, and EMT through the NF- $\kappa \mathrm{B}$ signaling pathway in hepatocellular carcinoma. Tumour Biol 37: 3461-3468, 2016.
15. Lee MY, Chou CY, Tang MJ and Shen MR: Epithelial-mesenchymal transition in cervical cancer: Correlation with tumor progression, epidermal growth factor receptor overexpression, and snail up-regulation. Clin Cancer Res 14: 4743-4750, 2008.

16. Strippoli R, Benedicto I, Pérez Lozano ML, Cerezo A, LópezCabrera M and del Pozo MA: Epithelial-to-mesenchymal transition of peritoneal mesothelial cells is regulated by an ERK/NF-kappaB/Snail1 pathway. Dis Model Mech 1: 264-274, 2008.

17. Huber MA, Azoitei N, Baumann B, Grünert S, Sommer A, Pehamberger H, Kraut N, Beug $\mathrm{H}$ and Wirth T: NF-kappaB is essential for epithelial-mesenchymal transition and metastasis in a model of breast cancer progression. J Clin Invest 114: 569-581, 2004.

18. Huber MA, Beug $\mathrm{H}$ and Wirth T: Epithelial-mesenchymal transition: NF-kappaB takes center stage. Cell Cycle 3: 1477-1480, 2004.

19. Dong XE, Ito N, Lotze MT, Demarco RA, Popovic P, Shand SH, Watkins S, Winikoff S, Brown CK, Bartlett DL, et al: High mobility group box I (HMGB1) release from tumor cells after treatment: Implications for development of targeted chemoimmunotherapy. J Immunother 30: 596-606, 2007.

20. Wang H, Bloom O, Zhang M, Vishnubhakat JM, Ombrellino M, Che J, Frazier A, Yang H, Ivanova S, Borovikova L, et al: HMG-1 as a late mediator of endotoxin lethality in mice. Science 285: 248-251, 1999.

21. Klune JR, Dhupar R, Cardinal J, Billiar TR and Tsung A: HMGB1: Endogenous danger signaling. Mol Med 14: 476-484, 2008.

22. Olkhanud PB, Damdinsuren B, Bodogai M, Gress RE, Sen R, Wejksza K, Malchinkhuu E, Wersto RP and Biragyn A: Tumor-evoked regulatory $B$ cells promote breast cancer metastasis by converting resting $\mathrm{CD} 4^{+} \mathrm{T}$ cells to T-regulatory cells. Cancer Res 71: 3505-3515, 2011.

23. Tian J, Avalos AM, Mao SY, Chen B, Senthil K, Wu H, Parroche P, Drabic S, Golenbock D, Sirois C, et al: Toll-like receptor 9-dependent activation by DNA-containing immune complexes is mediated by HMGB1 and RAGE. Nat Immunol 8: 487-496, 2007.

24. Sha Y, Zmijewski J, Xu Z and Abraham E: HMGB1 develops enhanced proinflammatory activity by binding to cytokines. $\mathrm{J}$ Immunol 180: 2531-2537, 2008.

25. Yang D, Chen Q, Yang H, Tracey KJ, Bustin M and Oppenheim JJ: High mobility group box-1 protein induces the migration and activation of human dendritic cells and acts as an alarmin. J Leukoc Biol 81: 59-66, 2007.

26. Lynch J, Nolan S, Slattery C, Feighery R, Ryan MP and McMorrow T: High-mobility group box protein 1: A novel mediator of inflammatory-induced renal epithelial-mesenchymal transition. Am J Nephrol 32: 590-602, 2010.

27. He M, Kubo H, Ishizawa K, Hegab AE, Yamamoto $Y$, Yamamoto $\mathrm{H}$ and Yamaya $\mathrm{M}$ : The role of the receptor for advanced glycation end-products in lung fibrosis. Am J Physiol Lung Cell Mol Physiol 293: L1427-L1436, 2007.

28. van Beijnum JR, Buurman WA and Griffioen AW: Convergence and amplification of toll-like receptor (TLR) and receptor for advanced glycation end products (RAGE) signaling pathways via high mobility group B1 (HMGB1). Angiogenesis 11:91-99, 2008.

29. Sims GP, Rowe DC, Rietdijk ST, Herbst R and Coyle AJ: HMGB1 and RAGE in inflammation and cancer. Annu Rev Immunol 28: 367-388, 2010.

30. Palumbo R, Galvez BG, Pusterla T, De Marchis F, Cossu G, Marcu KB and Bianchi ME: Cells migrating to sites of tissue damage in response to the danger signal HMGB1 require NF-kappaB activation. J Cell Biol 179: 33-40, 2007. 